\title{
BIRDS OF GUNDLUPET, KARNATAKA
}

\author{
V.J. Zacharias*
}

\begin{abstract}
Asurvey of the bird fauna of Gundlupet faluk in Karnataka was carried out over a Period of about 7 years since 1985. Most of the observations were carried out in the Madahalli villoge, though observations were also carried out in the Gundlupet town; on the sides of the Ootty road, Mysore road, and Calicut road, Maddur, Hangla tank and Gopalaswami Betto. Altogether 148 birds were recorded from the area which included migrants and nomigrants. Species diversity is very low when compared to the wet zone areas. Many of the species encountered were observed in fewer numbers. Two interesting species, the Fulvous Whistling Duck and Black Ibis were recorded. Both these species were also observed nesting in the area, which are new records.
\end{abstract}

\section{Introduction}

Gundlupet taluk $\left(11^{\circ} 35^{\prime} 34^{\prime \prime} \mathrm{N}, 76^{\circ} 12^{\prime} 17^{\prime \prime} \mathrm{E}-11^{\circ} 57^{\prime} 02^{\prime \prime} \mathrm{N}, 76^{\circ} 51^{\prime}\right.$ $32^{\prime \prime} \mathrm{E}$ ) in southwestern Karnataka, located in the rain shadow region of the Western Ghats is an open dry country. The moist deciduous forests in Wynaad plateau changes into deciduous and dry deciduous forests in the eastern direction as one moves from Wynaad to Gundlupet where the forest is stunted in growth. This change in vegetation is influenced by, the shortage of rain; as the eastern limit of monsoon is reached, the country becomes open and dry.

The country is mostly flat with isolated hills/hillocks with large rocks and thorny shrub. The area gets little rain from the Northeast monsoon. Because of the

'Department of Biology, Northern Virginia Community College', Manassas, Virginia, USA. 
scarcity of rain, vegetation is scanty. Natural vegetation consists of few scattered trees and thorny scrub. Trees grow in places where rain water is retained at least for a short period. There are a number of tanks/lakes around. Traditional system of agriculture depends on the availability of rain. Different types of cereals pulses, peanuts and vegetables are grown. However areas where ground water is available, are irrigated and cultivated. Sugar cane is a major cultivation in some areas, while coconut plantation and mango orchards grow well in some areas. Figs on the sides of major roads are grown well and support a number of frugivorous birds, bats, palm squirrels and Bonnet Macaques.

William Davison (1883) has made the pioneer survey of the birds of Gundlupet and surrounding areas of southwestern Karnataka. Hunting records of Phythian Adams (1943) in 1930s and the report on the Mysore bird survey (1939-40) by Salim Ali (1942-43) were the subsequent documents on the ornithology of the area. These reports have shown that the area harboured interesting bird fauna though the number of species was less.

There are no recent records on the bird fauna of the area. Since March 1985 and March, I was a frequent visitor to Gundlupet and surveyed the bird fauna of Gundlupet town; on either side of the Ootty road, Hangla, Mysore road, the Calicut road, Maddur, and portions of Burgi and Madahalli villages.

Most of the observations were carried out in the Madahalli village. I stayed at a 65 acre farm owned by the CMI congregation (Here in after referred to as Farm). The farm is located in a valley bordered on the two sides by rocky hills which are grown with thorn scrub-the natural vegetation of the area. The area between the farm and the hills are grassy and grown with scattered trees. The areas around the farm harboured Jackal., Porcupine, Blacknaped Hare, Varanus, snakes and toads. There was a small pond on one side of the farm near the hill surrounded by grasses and reeds harbouring frogs. The farm is well irrigated and mostly grown with mango trees and coconut palms. I have continued my visit every year till 1992, in different months of the year and noted birds in different areas.

The following abbreviations are used in the text; (SA) Salim Ali; (PA) Phythian Adams; (WD. William Davison. Nomenclature follows: Grimmet, Carol Inskipp and Tim Inskipp (1998)

\section{Systematic List of Birds}

GREY PARTRIDGE Francolinus pondicerionus frequently noted in the farm amid grasses. Ali (1943-44) has recorded it from Maddur. Occasionally caught by nomadic people along with the Bush Quails and the Blacknaped Hare 
RAIN QUALL Coturnix coromandelica not seen. WD saw it near Gundlupet JUNGLE BUSH QUAlL Perdicula asiatica-noted in the farm in grasses

INDIAN PEAFOWL Pavo cristatus- not seen. WD saw them abundant in the viscinity of Maddur.

FULVOUS WHISTLING DUCK Dendrocygna bicolor- The( late) Fr Thomas, my colleague and Professor of Zoology at St. Joseph College, who managed the farm was a good naturalist. He told me about a "Large chestnut coloured wild Duck" laying eggs in the bottom of a large pit in the farm in September 1984. The farm workers took the 7 eggs in the clutch and brought to him. ! visited the farm in October but could not find the bird in the farm area. But one of the workers told us that he has seen the bird in an earthen dam near Gundlupet. I visited the dam with Fr Thomas and we found the bird near the edge of the water in the dam. It was a Fulvous Whistling Duck. We have also found two Lesser Whistling Ducks in the dam. In fact very little information is available about the distribution of Fulvous Whistling ducks in S.India. Salim Ali didn't see it in his Mysore survey. Phythian Adams shot only a single specimen from a small flock during 14 seasons shooting in Mysore; at Nanjangud

LESSER WHISTLING DUCK Dendrocygna javanica- noted in the tanks. This as well as the following species of Waterfowl are caught by local people for eating.

BARHEADED GOOSE Anser indicus-not seen. P A has seen them at Gundlupet and Nanjangud feeding in paddy stubbles. He has shot 28-migrant

COMB DUCK Sarkidiornis melonotus -not noted. PA has seen only 2 near Gundlupet during his 16 years in Mysore

COTTON PYGMY-GOOSE NeHtapus coromendelianus-noted at Hangla

SPOTBILLED DUCK Anas poecilorhyncha-noted at Hangla

NORTHERN SHOVELER Anas clypeata - not seen- SA noted it at Hangla-migrant COMMON TEAL Anas crecca - not seen. According to WD very numerous

NORTHERN PINTAIL Anas acuta- Not seen- SA noted it in the Hangla - migrant

GARGANEY Anas querquedula-noted it at Hangla and in a tank near Maddur migrant

GOLDENBACKED WOODPECKER Dinopium benghalense- noted at Maddur and near the Ootty road and Hangla

RUFOUS WOODPECKER Celeus brochyurus noted at Maddur.

BROWNHEADED BARBET Megalaima zeylanica-Endemic to the subcontinent noted near the Burgi village.

WHITECHEEKED BARBET Megalaima viridis- Endemic to Western Ghats and associated hills noted at Maddur and near the Ootty road. S.D Ripley (Smithsonian Institution,USA) has collected specimens from Gundlupet in 1947 
COPPERSMITH BARBET Megalaima haemacephala - noted in the farm, village, town-nesting.

INDIAN GREY.HORNBILL Ocyceros birostris Endemic to the subcontinent noted on Figs on the Ootty road

CEYLON HOOPOE Upupa epops- noted in the farm-not common

INDIAN ROLLER Coracias benghalensis noted in all the areas, several in the farm on $27 / 4 / 88$

COMMON KINGFISHER Alcedo atthis-noted in the farm, Hangla

WHITETHROATED KINGFISHER Halcyon smyrnensis-noted in the farm and around Madahalli village

SMALL GREEN BEE EATER Merops orientalis- noted in all the areas covered.

BANDED BAY CUCKOO Cacomantis sonneratii noted in the farm on two occasions ASIAN KOEL Eudynamys scolopacea- noted in the town-common

GREATER COUCAL Centropus sinensis-noted in the farm not uncommon

VERNAL HANGING PARROT Loriculus vernalis-noted in the farm, town and near the. Ootty road

ALEXANDRINE PARAKEET Psittocula eupatria noted in the town and around

ROSERINGED PARAKEET Psittacula krameri noted in all the areas covered in this survey-

PLUMHEADED PARAKEET Psittacula cyanocephala Endemic to the subcontinentnoted in the farm, town, near the Ootty road and Gopalaswami Betta.

BROWNBACKED NEEDLETAIL. Hirundapus giganteus- not seen-SA noted it at Maddur

ASIAN PALM SWIFT Cypsiurus balasiensis noted in the farm and the town HOUSE SWIFT Apus affinis noted in the town

EURASIAN EAGLE OWL Bubo bubo noted in the farm and town near the Ootty road

MOTTLED WOOD OWL Strix ocellata noted in the farm-SA collected specimen SPOTTED OWLET Athene brama-noted in the farm where it nested-common INDIAN NIGHTJAR Caprimulgus asiaticus noted in the farm in the grassy areas near the hills

ROCK PIGEON Columba livio noted in all areas covered in this survey.

LAUGHING DOVE Streptopelia senegalensis-noted in the hills near the farmcommon 
SPOTTED DOVE Streptopelia chinensis- noted in al areas covered in this surveycommon

EURASIAN COLLARED Dove Streptopelia decaocto hills near the farm

WHITEBREASTED WATERHEN Amaurornis phoenicurus noted in the farm and Hangla

COMMON MOORHEN Gallinula chloropus Gundlupet lakes according to WD GREEN SANDPIPER Tringa ochropus not noted -SA noted it at Hangla

COMMON SANDPIPER Actitis hypoleucos noted it in the farm and at Hangla

GREATER PAINTED SNIPE Rostatula benghalensis not noted - Phythian Adams has taken eggs at Gundlupet.

BLACKWINGED STILT Himantopus himantopus - noted in the farm

PACIFIC GOLDEN PLOVER Pluvialis fulva - not noted - PA has shot one between Gundalupet and Begur

YELLOWWATTLED LAPWING Vanellus malabaricus - Endemic to the subcontinent noted near the farm.

REDWATTLED. LAPWING Vanellus indicus - noted in the farm, Maddur and Hangla INDIAN COURSER Cursorius coromandelicus - PA has noted it near Gundalupet. ORIENTAL HONEY BUZZARD Pernis ptilorhyncus - noted near the Ootty road BLACKSHOULDERED KITE Elonus caeruleus - noted in the farm and near Maddur BLACK KITE Milvus migrans - noted near the farm and near the fown BRAHMINY KITE Haliastur Indus - noted in the farm and at Hangla WHITERUMPED VULTURE Gyps bengolensis - noted near Maddur CRESTED SERPENT EAGLE Spilornis cheela - noted near the farm, Maddur SHIKRA Accipiter badius - noted in the farm and near the Ootty road CHANGEABLE HAWK EAGLE Spizaetus cirrhatus - Maddur COMMON KESTREL Falco tinnunculus - noted in the farm, outside the farm and Maddur

LEGGAR FALCON Falco iugger - A.O. Hume shot it near Gundlupet according to WD.

PERIGRINE FALCON Folco peregrinus - noted near the farm

LITTLE GREBE Tachybaptus ruficollis - noted at Hangla

ORIENTAL DARTER Anhingo melanogaster - Gundlupet lakes according to WD.

LITTLE CORMORANT Phalacrocorax niger - noted near Maddur and Hangla 
LITTLE EGRET Egretta garzetta - noted in the farm, Hangla GREAT EGRET Casmerodius alba - noted in the farm, Hangla INTERMEDIATE EGRET Mesophoyx intermedia - noted in the farm, near Hangla CATTLE EGRET Bubulcus ibis - noted in the farm,outside the farm, Maddur INDIAN POND HERON Ardeola grayii - noted in the farm, Maddur, Hangla BLACK IBIS Pseudibis papillosa - two birds were noted in the farm for the first time in early March 1985. They successfully nested on a $12 \mathrm{~m}$ high coconut palm on March 15,1985. Six birds were seen in June 1985. Two pairs nested in March 1987 and continued nesting in successive years; in March. PA has reported it at Gundlupet, but neither he nor SA has reported its nesting.

EURASIAN SPOONBILL. Platalea leucorodia - not noted.PA has noted it at Gundlupet.

SPOTBILLED PELICAN Pelicanus philippensis - noted near Nanjangud.

PAINTED STORK Mycteria leucocephala - noted at Hangla.

ASIAN OPENBILL Anastomus oscitans - noted at Hangla

WOOLLYNECKED STORK Ciconia episcopus - noted in the farm and Hangla.

GLODFRONTED CHLOROPSIS Chloropsis aurifrons - noted in the farm and near the Ootty road

BROWN SHRIKE Lanius cristatus - noted in the farm migrant

LONGTAILED SHRIKE Lanius schach - near the town

RUFOUS TREEPIE Dendrocitto vagabunda - Maddur, Ootty road

HOUSE CROW Corvus splendens - noted in and around the town

LARGEBILLED CROW Corvus macrorhynchos - noted in the farm

EURASIAN GOLDEN ORIOLE Oriolus oriolus - noted in the farm, town, and near the Ootty road

LARGE CUCKOO SHRIKE Coracina macei - in the farm, town

BLACKHEADED CUCKOO SHRIKE Coracina melanoptera - in the farm, town

SMALL MINIVET Pericrocotus cinnamomeus - noted in all the areas covered in this report.

BARWINGED FLYCATHER SHRIKE Hemipus picatus - noted in the farm, near the Ootty road

WHITEBROWED FANTAlL Rhipidura oureola - noted in the farm, town

BLACK DRONGO Dicrurus macrocercus - noted in all the areas covered.50+ were found roosting on a mango tree in the farm $5 / 12 / 87$ 
ASHY DRONGO Dicrurus leucophaeus - notes in the farm-rare migrant WHITEBELLIED DRONGO Dicrurus coerulescens - noted in the farm, Maddur ASIAN PARADISE FLYCATCHER Terpsiphone paradise - noted in the farm-migrant COMMON IORA Aegithina tiphia - noted everywhere-in small numbers only COMMON WOODSHRIKE Tephrodornis pondicerianus noted in the farm, town BLUE ROCK THRUSH Monficola solitarius - noted in the farm only once-migrant ASIAN BROWN FLYCATCHER Muscicapa dauurica - noted everywhere rare VERDITOR FLYCATCHER Eumyias thalassina-rare- noted in the farm every year and also at Gopalaswami Betta - migrant

ORIENTAL MAGPIE ROBIN Copsychus saularis - noted in the farm, town near Ootty road and Gopalaswami Betta.

INDIAN ROBIN Saxicoloides fulicata - noted in the farm and around, other open areas

BLACK REDSTART Phoenicurus ochruros - noted at Hangla.

COMMON STONECHAT Saxicola torquata - noted in the farm

PIED BUSHCHAT Saxicola caprata - noted in the farm fairly common Maddur

CHESTNUTTAILED STARLING Sturnus malabaricus - noted in the farm, town migrant

BRAHMINY STARLING Sturnus pagodarum - noted in the farm, Maddur, town ROSY STARLING Sturnus roseus - noted in the farm- migrant

COMMON MYNA Acridotheres tristis - noted everywhere-nesting observed

JUNGLE MYNA Acridotheres fuscus - noted in the farm, Maddur

GREAT TIT Parus major - noted in the farm, town, near Ootty road

BARN SWALLOW Hirundo rustica - noted in the farm, Maddur-migrant

WIRETAILED SWALLOW Hirundo smithii - noted in the farm, Maddur

REDRUMPED SWALLOW Hirundo daurica - noted in the farm, Maddur, Hangla

REDWHISKERED BULBUL Pycnonotus jocosus - noted in the farm, Maddur near the Ootty road and Gopalaswami Betta -common

REDVENTED BULBUL Pycnonotus cafer - noted in all the areas covered observed nesting.

WHITEBROWED BULBUL Pycnonotus luteolus - Endemic to the Subcontinentnoted in the farm and Maddur

ZITTING CISTICOLA Cisticola juncidis - noted in the farm, sugar cane fields observed nesting 
GREYBREASTED PRINIA Prinia hodgsonii - noted in the farm near the hills in the grasses

ASHY PRINIA Prinia socialis - noted in the farm.

PLAIN PRINIA Prinia inornata - noted near the farm

ORIENTAL WHITE EYE Zosterops palpebrosa - noted in the wooded areas of the farm, town

BLYTH'S REED WARBLER Acrocephalus dumetorum - noted in the farm fewer numbers-possibily on "transit". -migrant

CLAMOROUS REED WARBLER Acrocephalus stentoreus - noted in the farm, near Ootty road and Hangla

COMMON TAYLOR BIRD Orthotomus sutorius - noted everywhere in smaller numbers.

GREENISH WARBLER Phylloscopus trochiloides - noted in the farm, town, near Ootty road-migrant

TAWNYBELLIED BABBLER Dumetia hyperythra - noted near the farm in the scrub habitats.

YELLOWEYED BABBLER Chrysoma sinensis SA - noted at Gundlupet

LARGE GREY BABBLER Turdoides malcolmi - noted in the farm, different parts of Madahalli Village, near the Ootty road observed nesting.

JUNGLE BABBLER Turdoides striatus - near Maddur in the deciduos forests -

WHITEHEADED BABBLER Turdoides affinis - noted outside the farm, open areas of Madahalli village, Maddur.

RUFOUSWINGED BUSHLARK Mirafra assamica - noted in the open areaseverywhere

ASHYCROWNED SPARROW LARK Eremopterix grisea - Endemic to the subcontinent-noted in the grassy hiils of the farm-observed nesting.

MALABAR LARK Galerida malabarica - Endemic to the subcontinent noted in the farm, Maddur

ORIENTAL SKYLARK Alauda gulgula - noted in the farm open areas

PALEBILLED FLOWERPECKER Dicaeum erythrorynchos - noted in the farm in the wooded areas.

PURPLERUMPED SUNBIRD Nectarinia zeylonica - noted in the farm near the hills PURPLE SUNBIRD Nectarinia asiatica noted in the farm, town, HOUSE SPARROW Passer domesticus - noted everywhere 
CHESTNUTSHOULDERED PETRONIA Petronia xanthocollis - noted outside the farm, town

WHITEBROWED WAGTAIL Motacilla maderspatensis - noted in the farm, town, Hangla

YELLOW WAGTAIL Motacilla flava - noted in the farm and near the Ootty roadmigrant

Grey wagtail Motacilla cinera noted in the farm, near ootty road, Gopalswami Betta

Hangla- migrant

Paddyfield Pipit Anthus rufulus noted in the farm, open areas

Streaked Weaver Ploceus manyar PA collected eggs from two nests

Baya Weaver Ploceus philippinus noted near the Ootty road-observed nesting

\section{Discussion}

Altogether 146 species of birds were recorded in and around Gundlupet. This included 79 nonpasserines and 67 passerines. Of these, 21 species were migrants and others residents. Three species reported by William Davison and six species reported by Pythian Adams and Salim Ali were not met with during this survey. Ninetysix species were recorded from the farm and around, probably due to the diversification of ecological niches and the protection given. Thirty species were associated with wetland habitats which is about $20 \%$ of the total number of birds recorded from the area. Fifteen species were frugivores/granivores, 84 were insectivores and 15 raptors.

Fiffeen species of birds were endemic to the subcontinent. Species diversity is very low and of the 148 species reported, only very few were observed in good numbers in all the areas surveyed. This may probably due to the low quality of the habitat. The largest number of birds were recorded from Maddur probably because of the edge effect.

Discovery of the Fulvous Whistling Duck and Black lbis and their nesting are interesting, as very little information is available on these species from south India. It was also interesting to note that both these species nested in the farm where the birds were protected. However bird fauna thrived well in areas with water and fruiting trees and are least disturbed.. 


\section{Acknowledgement}

I thank Fr. Thomas (the late) who helped me to conduct a bird survey in Gundalupet. His warm hospitality, help in transportation and constant encouragement is gratefully acknowledged. He wanted to compile a list of bird in the area, especially in the farm which unfortunately couldnot be done before his accidental death. I am also grateful to Fr. John. My sincere thanks are due to James, Dean, Dept of Ornithology and Martha Rosen and others of the library of the National Museum of Natural History, Smithsonian Institution, Washington, D.C., for their help.

\section{References}

1. Ali, S 1942-43. The birds of Mysore. with notes by Hugh Whistler. J.Bombay Nat.Hist.Soc.Vol 43 and 44.

2. Davison, W 1883. Notes on some birds collected on the Nilghiris and in parts of Wynaad and southern Mysore. Stray Feathers 10,6:329-419.

3. Grimmet, R, Carol Inskipp and Tim Inskipp 1998. Birds of the Indian Subcontinent. Helms, London.

4. Phythian-Adams E.G 1940 Small Game Shooting in Mysore. J.Bombay Nat.Hist.Soc. Vol.47(3) 594-603. 